\title{
PRINCIPLES AND PROBLEMS OF FINANCIAL PROVISION OF EDUCATION TO PERSONS SENTENCED TO IMPRISONMENT
}

\author{
Oleksandr Prasov', Yuliia Abakumova²
}

\begin{abstract}
The purpose of the article is to study the economic and legal problems of financing the education of persons sentenced to imprisonment, realization of their constitutional right and to propose to eliminate existing gaps in the legislation. Methodology. The survey is based on an analysis of the principles of financing education, including prison education, on the procedure and problems of financing education for persons sentenced to imprisonment. The principles, good practice and problems of providing educational services in Singapore, Japan, Hong Kong, South Korea, Finland, the Netherlands, Canada, Poland, Germany, Ireland, Great Britain, the USA, Estonia, Kazakhstan, Ukraine, the Russian Federation are considered. Sourcing of education (state, non-state and mixed) are investigated. The analysis of macro indicators of social and economic development of the countries, in which certain system of financing of education operates, is carried out. Emphasis is placed on the fact that the country's development largely depends on the share of gross domestic product spent on research. Only if the cost of science exceeds $0.9 \%$ of gross domestic product, it can be said about the impact of science on the development of the state economy. It is concluded that most European countries use the so-called principle of "funding formula", according to which the state allocates financial resources to higher education institutions in amounts determined by special indicators, such as high quality of education, number of students, labor intensity and material consumption of the education process. Results. In the process of studying the state policy on financing the educational system, it has been concluded that the most developed countries with a sufficiently high level of gross domestic product per capita have the state system of financing higher education. The main positive feature of penitentiary educational systems is their focus on the prisoner as an individual to provide his or her needs, the opportunity to acquire professional skills and, in the future, to integrate into society and restore his or her social status easily. The authors also conclude that due to certain difficulties in obtaining education by prisoners, namely, most of these persons cannot get an education because they are in isolation from society, their attendance at school is impossible, the way out of this situation is distance learning. Practical implications. Proposals have been made, according to which higher education for persons sentenced to imprisonment should be regarded as paid activity along with work, and the possibility of obtaining distance education should be enshrined in law. Value/originality. The article provides proposals for amendments to the legislation in the field of education for persons sentenced to imprisonment in some post-Soviet countries for the harmonization of regulations.
\end{abstract}

Key words: right to education, system of education, sourcing, budgetary facilities, imprisonments, realization of right to education.

JEL Classification: A12, A13, D63, H52

\section{Introduction}

Persons sentenced to imprisonment remain citizens of their state, and, accordingly, they are subject to all rights, legitimate interests and legal obligations of human and citizen, except for restrictions related to the fact of their imprisonment.

One of the purposes of imprisonment of a person who has committed a crime is his or ehr correction and resocialization. Correction is the process of positive changes that occur in the personality of the offender and create his or her readiness for self-directed lawabiding behavior. In turn, resocialization is a conscious restoration of a prisoner in the social status of a full member of society, his or her return to an independent generally accepted social normative life in society (Criminal Executive Code of Ukraine, 2004).

\footnotetext{
Corresponding author:

${ }^{1}$ District Administrative Court, Ukraine.

E-mail: PAAZU@ukr.net

${ }^{2}$ Classical Private University, Ukraine.

E-mail: Julia_v_abakumova@ukr.net
} 
The Constitution of each developed country provides the rights and responsibilities of human and citizen, including the right to education. In most European countries, the country ensures a complete general secondary education accessible to everyone. There is also state funding not only for preschool, complete secondary education, but also vocational and higher education (Maklakov, 1999).

In view of the above, it can be argued that persons sentenced to imprisonment have the right to education, as well as any other citizen of the country.

The following scientists devoted their scientific works to the study of problems related to ensuring the right to education of persons sentenced to imprisonment: H. A. Avanesov, M. L. Ahranovych, Yu. M. Antonian, V. A. Badyra, A. V. Bailov, O. I. Bohatyrova, V. O. Boniak, O. V. Vakulenko, O. V. Haltsova, A. V. Hradetskyi, O. V. Honcharenko, D. V. Zahula, Ya. S. Ivasenko, O. M. Kozhevnykova, Yu. O. Matvieieva, O. V. Poletaiev, A. Kh. Stepaniuk, S. V. Siur, A. V. Fadieieva, etc. When representing significant scientific value, most studies lack the implementation of the right to education by persons sentenced to imprisonment and the problems of its sourcing.

The purpose of the article is to study the economic and legal problems of financing the education of persons sentenced to imprisonment, realization of their constitutional right and to propose to eliminate existing gaps in the legislation.

\section{Modern principles and problems of sourcing the educational system}

Effective education of the population of any country acts not only as a driving force of political, economic, technical progress, but also as a basis of national consciousness, patriotism, desire of constant selfimprovement and increase of the countrie's potential. Knowledge, information and the ability to use them correctly are the greatest resource and factor of economic growth. Education performs one of the most important functions: to provide the state with the necessary qualifications (Kozarezenko, 2010).

World experience shows that most of the country's development largely depends on the share of gross domestic product (hereinafter referred to as GDP), which is spent on research, and only if the cost of science exceeds $0.9 \%$ of GDP, it can be said about the impact of science on development of economics (Malitskyi, 2004). However, not every state is able to create the necessary conditions for the development of science and sufficient funding for education.

Given the above, it is worth paying attention to the principles of financing the educational process in countries with the best educational systems, including the United Kingdom, Hong Kong, Ireland, Canada, the Netherlands, Germany, South Korea, Poland, Singapore, Finland, Japan and some others.
According to the official world ranking of education, we currently have the following situation. The first place is occupied by Singapore, then: 2. Hong Kong; 3. South Korea; 4. Japan; 5. Taiwan; 6. Finland; 7. Estonia; 8. Switzerland; 9. the Netherlands; 10. Canada; 11. Poland; 12. Vietnam; 13. Germany; 14. Australia; 15. Ireland; 16. Belgium; 17 . NewZealand; 18. Slovenia; 19. Austria; 20. the United Kingdom; 21. the Czech Republic; 22. Denmark; 23. France; 24. Latvia; 25. Norway; 26. Luxembourg; 27. Spain; 28. Italy; 29. the USA; 30. Portugal; 31. Lithuania; 32. Hungary; 33. Iceland; 34. Russia; 35. Sweden; 36. Croatia; 37. Slovakia; 38. Ukraine; 39. Israel; 40. Greece, etc. The states of Africa were the last (Kohlan, 2015).

This result is particularly surprising, given that until the 1960s, Singapore had one of the highest levels of illiteracy. It is safe to say that an effective educational system plays a key role in the country's success. The Singapore government does not spare funds for the education of its citizens. Every year, 12.1 billion USD is invested in this area (Kohlan, 2015).

In general, in many Asian countries, schools expect high results from each student. There is a lot of impulse, focus and consistency, as these countries are able to attract the most talented teachers, which accordingly implies a high level of sourcing for the educational system (Kohlan, 2015). For example, Japan, a country with the highest level of technology, has such potential, not least due to reforms in the educational system. In this country, the educational model has been completely changed and an effective system of quality control has been created. The literacy rate in Japan is $99.9 \%$, despite the fact that only primary education is compulsory (The best Educational Systems in the World, 2018).

The people of Hong Kong have the highest IQ on the planet. This country is characterized by high achievements in the field of technology due to the excellent educational system. Education in Hong Kong is built on the same model as in the United Kingdom. It is under the control of the Bureau of Education and the Department of Social Security. 12-year education is compulsory in the state. The government encourages private primary and secondary schools that have achieved a fairly high standard of education. Such schools are awarded a subsidy, which is provided according to the number of students (The best educational systems in the world, 2018).

South Korea's educational system is developing rapidly. The country is the leader in the number of people obtained higher education. Education is the main life position of the country's population. The schools have the most comfortable conditions for learning, in particular, each student is provided with a personal locker, primary classes are taught separately from secondary and high school, each class of primary school has a special place for recreation and a creativity 
area. Elder students study in rooms equipped with a TV, blackboard and, in some cases, an interactive screen. Schools have a football field, a sports field, and in addition, there may be a swimming pool, archery and golf court, a small garden or a mini-arboretum, which is cared for by children. The annual budget for education in South Korea is 11.3 billion USD (Khshanovych, 2018).

Finland implements a special approach to the educational process, which is expressed in the fact that schoolchildren and students are given maximum freedom. Education is free, food is also provided if the student is present at school full time. The country pays great attention to attracting applicants to higher education institutions. Finland has a fairly large budget for education: 11.1 billion EUR per year (Yurchenko, 2019).

The educational system of the Netherlands is efficient. Firstly, educational institutions in this country are divided into religious and public. Education is free at all levels. In some cases, private schools still require tuition fees, including for additional educational services. A feature of the educational system in the Netherlands is that students under the age of sixteen are required to devote a full day to education. In the future, they have the right to choose the opportunity to receive higher education and, accordingly, to study full or part time freely (The best educational systems in the world, 2018).

In Canada, the quality of education is quite high, as the government pays great attention to its standards. Education is mainly funded by the government of each individual province. The Canadian educational system is unique as it integrates materials from different cultures into the curriculum, so students have the opportunity to perceive the world from different perspectives from childhood (Yurchenko, 2019).

Poland is the first country in the world to have its own Ministry of Education. This state has high literacy rates. Compulsory education lasts 9 years. After graduation, a person has the opportunity to enter a lyceum or college. Polish higher education is recognized in many countries due to its consistently high quality. The European system of higher education is practiced in the country. There are two admission campaigns per year to higher education institutions, which avoids the loss of a student for the entire academic year. $70 \%$ of Polish students are taught in English (The best educational systems in the world, 2018).

The German educational system is deservedly considered one of the best in the world. Compulsory education in the state lasts 9 years. As for the German higher educational system, it is funded by the state and belongs to the institutions of public administration. The number of private higher education institutions is about $10 \%$ of the total. They are, in most cases, related to legal and economic specialties. $10 \%$ of the budget of German higher education institutions comes from the federal government, and $90 \%$ - from the federal lands. The German government is also making significant investments in the development of domestic science. Thus, in 2005, an additional 6 billion EUR was allocated for the government's Best of the Best program (Otroshchenko, 2018).

Ireland's educational system is also considered one of the best, as education in this country is absolutely free at all levels, including higher education and colleges. Currently, the emphasis in education is on learning and teaching in Irish. In the state, education is compulsory for all children. All educational institutions, including private ones, are fully funded by the government in order to provide free and quality education at all levels and to all residents of the country (The best educational systems in the world, 2018).

The UK is well known around the world for the quality of its education not only at the school level but also at the higher education level. University of Oxford is the number one university in the world. In the UK, education is largely funded by the state. There is also a form of sourcing such as a grant, which is issued taking into account the government's priorities for the development of science and education. The award of the grant mainly depends on the indicators of the number of students, the complexity and material intensity of their education. Also, significant financial resources are allocated to support talented youth (Malik, 2014).

The United States ranked 29th in the above ranking, behind successful European countries in terms of schooling, indicating the need to improve the quality of education in the country, especially given that according to a study by the National Center for Quality of Personnel Education increasing the level of education of employees by $10 \%$ improves their productivity by $8.6 \%$, while increasing the same amount of investment in technical equipment leads to the development of productivity by only $3.4 \%$ (First Findings from the EQW National Employer Survey, 2017).

Among the countries of the post-Soviet space, the Estonian educational system is the most effective, which ranks seventh in the world education ranking. According to the results of PISA in 2015, this country is among the ten countries that have shown the greatest success in mathematics, science and reading, ahead of Finland. The Estonian educational system is characterized by such a feature that it strives for the maximum equality of its citizens, in particular with regard to ensuring the right to education. Education in Estonia, as in other Nordic and Baltic countries, is financed from the state budget. Private funding amounts a small share (Yurchenko, 2019).

In a post-Soviet state such as Kazakhstan, despite the financial crisis of the last 10 years, significant financial resources have been allocated for education. Budget funding for education increased by $10.7 \%$ and amounted to 627.3 billion KZT (Tuimebaiev, 2019). 
It is concluded that most European countries use the so-called principle of "funding formula", according to which the state allocates financial resources to higher education institutions in amounts determined by special indicators, such as high quality of education, number of students, labor intensity and material consumption of the education process, etc. (Yashchuk, 2019).

Thus, the effective provision of education of the population determines the rapid development and strengthening of the countries' economic position. However, if the provision of full general secondary education to the population, in civilized countries, is the responsibility of the state, the sources of funding for education, especially higher education, can be different, namely: public, private and mixed.

Public funding is possible in the form of: direct funding; additional allocations for certain categorical programs or activities; grants or subventions; targeted allocation of special material resources; granting benefits; granting a place in a higher educational institution by competition; implementation of specific programs for financing education (lending, voucher education, providing food for low-income children, etc.); according to a formula that takes into account certain quantitative and qualitative indicators of educational activities of a particular educational institution (Urusova, 2013). The system of public funding of higher education is effective, for example, in Germany, Norway, France, Sweden.

Implementation of non-public funding is possible as follows: funding for training in accordance with the concluded agreement on retraining; providing subsidies from local budgets; allocation of funds received by the educational institution for research or other work performed on behalf of organizations, enterprises, institutions or citizens; receiving income from the sale of products of training and production workshops, laboratories of enterprises; receiving funds from the lease of premises, buildings, equipment of the educational institution; payment for the provision of additional educational services or services to provide greater comfort during training; lending and lending by banks; receipt of dividends from securities and income from placement on time deposits of temporarily free funds; receiving by the educational institution from enterprises, institutions, organizations or citizens of voluntary monetary contributions or material values, in the order of sponsorship (Urusova, 2013). Such a system of financing higher education exists, in particular, in Australia, South Korea, the United States, and Japan.

Table 1

Macro indicators of socio-economic development of states with a state system of sourcing higher education

\begin{tabular}{|l|c|c|c|c|c|}
\hline \multicolumn{1}{|c|}{ Country } & Population & $\begin{array}{c}\text { GDP } \\
\text { (mln USD face value) }\end{array}$ & $\begin{array}{c}\text { GDP } \\
\text { (mln USD per capita) })\end{array}$ & $\begin{array}{c}\text { Public expenditure on } \\
\text { education (\% of GDP) }\end{array}$ & $\begin{array}{c}\text { Government spending } \\
\text { per } \\
1 \text { student (USD) }\end{array}$ \\
\hline Germany & 82800000 & 3466639 & 48111 & 4,81 & 6872.53 \\
\hline Norway & 5258317 & 370449 & 69249 & 7.55 & 13811.01 \\
\hline France & 67013000 & 2463222 & 42314 & 5.46 & 6590.46 \\
\hline Sweden & 10053200 & 511397 & 49836 & 7.55 & 14280.05 \\
\hline
\end{tabular}

Table 2

Macro indicators of socio-economic development of states with a non-public system of sourcing higher education

\begin{tabular}{|l|c|c|c|c|c|}
\hline \multicolumn{1}{|c|}{ Country } & Population & $\begin{array}{c}\text { GDP } \\
\text { (mln USD face value) }\end{array}$ & $\begin{array}{c}\text { GDP } \\
\text { (mln USD per capita) }\end{array}$ & $\begin{array}{c}\text { Public expenditure on } \\
\text { education (\% of GDP) }\end{array}$ & $\begin{array}{c}\text { Government spending } \\
\text { per 1 student (USD) }\end{array}$ \\
\hline Australia & 24458800 & 1258978 & 48899 & 5.32 & 5948.92 \\
\hline South Korea & 51446201 & 1411246 & 37740 & 5.25 & 7289.88 \\
\hline USA & 324973000 & 18569100 & 57436 & 4.99 & 6522.3 \\
\hline Japan & 126790000 & 4938644 & 41275 & 3.47 & 3047.7 \\
\hline
\end{tabular}

Table 3

Macro indicators of socio-economic development of states with a mixed system of sourcing higher education

\begin{tabular}{|l|c|c|c|c|c|}
\hline \multicolumn{1}{|c|}{ Country } & Population & $\begin{array}{c}\text { GDP } \\
\text { (mln USD face value) }\end{array}$ & $\begin{array}{c}\text { GDP } \\
\text { (mln USD per capita) }\end{array}$ & $\begin{array}{c}\text { Public expenditure on } \\
\text { education (\% of GDP) }\end{array}$ & $\begin{array}{c}\text { Government spending } \\
\text { per 1 student (USD) }\end{array}$ \\
\hline Great Britain & 65110000 & 2629188 & 42481 & 5.54 & 4120.21 \\
\hline Canada & 36539100 & 1529224 & 46437 & 7.1 & 15004.05 \\
\hline Ispania & 46812000 & 1232597 & 36416 & 4.28 & 4076.34 \\
\hline Italy & 60599936 & 1850735 & 36833 & 4.08 & 5396.7 \\
\hline
\end{tabular}


The mixed system of financing higher education is typical, for example, for Great Britain, Canada, Spain, Italy, and the post-Soviet states.

If we pay attention to the dependence of the types of financing of higher education on the macroeconomic indicators of socio-economic development of a particular state (in\% of GDP) (Zhuravel, Shynkaryk, 2020), we see the following result.

Expenditures on financing education at the expense of the state are provided by a separate item of the state budget. It is clear that the level of funding for education directly depends on the state budget. Therefore, the state system of financing higher education has the most developed countries with a fairly high level of GDP per capita. Unfortunately, not all countries have the ability to provide adequate funding for the educational system. In many cases, public funding is insufficient to implement all necessary educational programs, and attracting private investors makes educational institutions dependent on the latter. If we pay attention to the problems of financing higher education, for example, Ukraine, we can note the following. Despite the fact that the state has a fairly extensive and powerful system of higher education institutions of all forms of ownership, the share of their funding from the state is insignificant, and this percentage decreases every year. Over the last five years, budget funding for higher education in Ukraine has decreased (in\% of GDP) from 9 to $5.4 \%$. And this is not surprising, especially considering that, for example, in 2016, Ukraine ranked 138 th out of 189 countries in terms of GDP per capita (Kononenko, 2017).

In financing education, the state sees a socio-political component rather than investing in human potential, which threatens the country's development. Therefore, in order to ensure sufficient funding for education, in addition to budget funds, it is necessary to attract more funds from other sources of funding (lending, loans, grants, etc.).

And, for example, the main problems of the educational system of the Russian Federation (hereinafter referred to as Russia) are the lack of independence of recipients of budget funds and low managerial and financial and economic qualifications of managers of the educational system (Kaleniuk, 2017).

Based on the above, we can conclude that education is an important factor in economic and technological progress of any state. Each country has its own educational system, which is consistent with the national system of budget policy and its traditions.

\section{Principles and problems of sourcing education for persons sentenced to imprisonment}

As noted above, persons sentenced to imprisonment have equal rights with other citizens of the state, except for those rights that are limited by a court decision or by law. Therefore, like other citizens, such persons have the right to education. For the most part, such a right is explicitly stipulated in the relevant legislation of the country. For example, in accordance with Art. 8 of the Criminal Executive Code of Ukraine "Basic rights of convicts", convicts have the right: in penitentiaries, in accordance with the laws of Ukraine "On Education" and "On General Secondary Education", to ensure the availability and free of charge of full secondary education. General education and vocational training of convicts is carried out to promote the development of the individual, in order to correct and resocialize the person. In addition, it provides a system of knowledge, skills and abilities in the field of a particular speciality, which will be needed by a person after release (Criminal Executive Code of Ukraine, 2004). Convicts who wish to improve their general education level, regardless of age, are provided with conditions for selfeducation, given the opportunity to study in general educational institutions of colonies created by local executive bodies and local governments in accordance with their needs and with the necessary logistical and scientific methodical base, pedagogical staff in the manner prescribed by the Cabinet of Ministers of Ukraine (Part 2 of Art. 125 of the Criminal Executive Code of Ukraine). In addition, secondary schools of three levels are formed in educational colonies. Textbooks, notebooks and stationery are provided free of charge for convicts who study in these schools. For convicts who do not have a vocational profession for which they can be employed in this colony, it is possible to train in vocational training courses for workers in the workplace (Criminal Executive Code of Ukraine, 2004).

It can be noted that in this part the norms of the penitentiary legislation of Ukraine generally correspond to the European penitentiary rules, according to para. 28.1 of which each penitentiary institution should strive to provide all prisoners with access to educational programs which should be as comprehensive and meet individual needs of the prisoners and their aspirations. Para. 28.3 emphasizes that special attention should be paid to the education of young prisoners as well as prisoners with special needs (European Penitentiary Rules, 1987). And, according to the Standard Minimum Rules for the Treatment of Prisoners, "Prisoners who are able to benefit from this should be provided with the opportunity for further education, including religious education, in countries where this is permitted. Education of illiterate persons and young people should be considered compulsory, and prison authorities should pay special attention to it; the education of convicts should, as far as possible, be linked to the country's educational system so that released prisoners can continue their studies without complications" (para. 77) (Chechyn, 2016). 
In the case of training of convicts not only the constitutional right to education is realized, but also the horizons of the latter are expanded, it is possible to see and assess the existing reality, new needs of persons are formed, which can contribute to further correction and resocialization of the prisoners, which has a positive effect on increasing their employment. But the education of convicts has its own specifics, which concerns not only the process of its actual implementation but also funding. The main problem with such training is that the person is isolated from society. In addition, on the one hand, giving convicts the opportunity to receive education is a manifestation of humane treatment (humanization of the penitentiary system), on the other hand, often the need to receive education is perceived by prisoners as an additional punishment (Chechyn, 2016). In addition, in countries with insufficient budget support for the educational system, prisoner education is funded on a "residual basis". Therefore, the experience of those countries in which the level of GDP per capita is quite high, and at the same time, whose policy in the field of realization of the right to education of persons sentenced to imprisonment, has certain call points and standards may be useful. For example, in Finland a lot of attention is paid to the re-education and resocialization of convicts, significant funds are allocated for their training, various forms and methods of training are used, and special training courses are developed. Prisoners have the opportunity, if necessary, to study during working hours. External educational institutions are involved in cooperation (Yunkari, 2004). The main purpose of education in Finland, for the further resocialization of convicts, is to increase or improve their vocational skills. Convicts receive general education in this country, as in many other countries of the world, free of charge. In prison, they also have the opportunity to prepare for university entrance exams and, if successful, to continue their education there, even while in prison. If the prison library does not have the necessary literature to prepare for admission, prisoners can buy books in educational institutions or public libraries. In some cases, convicts may be allowed to study or work outside the prison without additional supervision (Shevchenko, 2015).

In German prisons, a large percentage of prisoners do not even have compulsory basic education. In order to remedy this situation in prisons, convicts are provided with education using an individual approach to each, which involves the development of a number of educational programs. General education is free. Convicts also have the opportunity to receive higher education. The end of a prisoner's vocational training occurs at the same time as the end of his sentence, so that a person can, immediately after release, integrate normally into public life. The organization of professional training of convicts and their professional development in places of imprisonment in Germany is carried out jointly by the administration of these institutions and a special trade union (Pshenychka, 2019).

Swedish prisons have all the necessary conditions for convicts to receive education. Vocational education is provided to prisoners at their request and is paid for from the budget. Distance learning and individual approach are used. A personal training program is developed for each prisoner, taking into account his or her needs, which can be continued after release. If a convict wishes to continue his or her education after release, he or she must inform the prison administration in advance in order to organize his or her admission to the relevant educational institution (Shevchenko, 2015).

In France, secondary education is compulsory, including for prisoners. The French penitentiary system is part of the Ministry of Justice and reports to the Prison Administration. It consists of 9 regional directorates, one mission dealing with overseas departments and territories, and one National School of Prison Administration. 186 institutions are subordinated to the prison administration, of which 119 are remand prisons, 55 are institutions for serving criminal sentences, 12 are autonomous centers of semi-free regime and one public institution of national health care (Aleksandrov, 2004). Much attention in French prisons is paid to the training of prisoners. Ensuring this opportunity is mainly entrusted to the organization of the GRETA system of National Education (Alexandrov, 2005). The main task of this organization is to ensure lifelong learning.

In the United States, the educational system in prisons is provided in a decentralized manner, which, in addition to federal prisons in the states, provides for local and private prisons. In order to adapt and resocialize convicts, they are provided with psychological services, education is provided in accordance with school and university curricula, the process of professional training is organized, they are given the opportunity to participate in religious groups, industrial production and agricultural work. Scholarships are paid to convicts during their studies at vocational training centers. Convicted persons who have not been prosecuted for a long time have the right to request free vocational training through the administration of the departments (Pshenychka, 2019).

The main positive feature of penitentiary educational systems is their focus on the prisoner as an individual to provide his or her needs, the opportunity to acquire professional skills and, in the future, to integrate into society and restore his or her social status easily. The most effective for places of imprisonment is the training of a convict by distance learning. The advantages of this method of education, first of all, are: providing prisoners with equal opportunities with other citizens to obtain education, ie the realization of their constitutional right; providing prisoners with an additional guarantee of choosing a profession after release; opportunity to practice at a convenient time and in a convenient place 
and mode; providing an unregulated period of time for the study of the discipline, which in the conditions of places of imprisonment is very relevant and so on (Hradetskyi, 2015). But such training requires the provision of appropriate information technology, which involves the allocation of significant financial resources. The budgets of many states cannot even afford to fund the education of prisoners. Therefore, it can be assumed that it is necessary to look for other sources of funding for education in prisons. Thus, if a person works in prison and receives a salary, a person could provide funding for his or her own education. However, if we draw a parallel in this area between the penitentiary system, for example, France and Russia, we can see that the latter prisoners are deprived of such an opportunity. The salary of French prisoners is about 300 USD a month, while in Russia it is about 10 USD. In addition, in French prisons, prisoners do not pay for food, while in Russia the state takes a significant portion of food from the salaries of convicts.

But when financing the penitentiary system of education, problems arise not only due to insufficient funds, but also due to inconsistencies in legislation in this area. Thus, for example, according to the Order of the Ministry of Justice of Ukraine No. 2823/5 dated Auguat 28, 2018 "On approval of the Rules of Procedure of penitentiary institutions", convicts have the right to receive education in accordance with the legislation on education (para. 2). At the same time, the Ukrainian legislation (Criminal Executive Code of Ukraine, 2004) deals only with the types and forms of education, but there is no indication of the procedure and methods of education. According to the law, the only way to obtain higher education in places of imprisonment in Ukraine is distance learning, given the lack of financial capacity to provide all the necessary technical base. Therefore, the legislation of Ukraine requires clearly defined rules for the education of persons sentenced to imprisonment.

There are other difficulties in obtaining education for prisoners. Most people sentenced to imprisonment cannot get an education because they are in isolation from society, and therefore it is impossible for them to attend school, because convicts are obliged to adhere to the regime of the penitentiary institution. Distance learning is a way out of this situation. But it not only needs funding, it also takes a long time. Therefore, attention should be paid to the experience of Finland, where prisoners have the opportunity to study during working hours. The European Penitentiary Rules also state: "Under the internal regime, the status of education must not be lower than the status of work, and prisoners must not be financially oppressed or otherwise involved in educational programs" (para. 28.4) (European Penitentiary rules, 1987). If the planned regime for convicts provides for their participation in educational or other programs during working hours, they should receive a monetary reward for it, as for work (para. 105.4.) (European Penitentiary Rules, 1987). That is, obtaining higher education by persons sentenced to imprisonment should be regarded as paid activity along with work, and the possibility of distance education should be enshrined in law, in connection with which the current criminal executive legislation of Ukraine needs to be amended.

\section{Conclusions}

The state policy on financing education, in particular, persons sentenced to imprisonment and exercising this constitutional right has been studied. The general characteristic of principles of financing of system of education in such countries as: Singapore, Japan, Hong Kong, South Korea, Finland, the Netherlands, Canada, Poland, Germany, Ireland, Great Britain, the USA, Estonia, Kazakhstan, Ukraine, the Russian Federation is given. Sourcing of education (state, non-state and mixed) are investigated. The analysis of macro indicators of social and economic development of the countries, in which certain system of financing of education operates, is carried out. The positive experience of providing educational services to persons sentenced to imprisonment in Finland, Germany, Sweden, France, and the USA is analyzed. Problems and peculiarities of providing educational services to persons sentenced to imprisonment in some post-Soviet states have been studied. In the course of the research it was concluded that the most developed countries with a sufficiently high level of GDP per capita have a state system of financing higher education. The main positive feature of penitentiary educational systems is their focus on the prisoner as an individual to provide his or her needs, the opportunity to acquire professional skills and, in the future, to integrate into society and restore his or her social status easily. The most effective for places of imprisonment is the training of a convict by distance learning.

\section{References:}

Criminal Executive Code of Ukraine. Information of the Verkhovna Rada of Ukraine (VRRU), 2004, № 3-4, Art. 21. Available at: https://zakon.rada.gov.ua/laws/show/1129-15

Maklakov, V. V. (1999). Constitutions of foreign states. 2nd edition. Moscow: BEC Publishing House, 584 p.

Kohlan Sean. World education ranking. NEWS Ukraine. Available at: https://www.bbc.com/ukrainian/ science/2015/05/150513_vj_education_rankings_it

The best educational systems in the world. Available at: https://rainbowschool.international/uk/luchshie-sistemyobrazovaniya-v-mire-top-10-stran/ 
First Findings from the EQW National Employer Survey / The National Center on the Educational Quality of the Workforce. Available at: https://www.census.gov/econ/overview/mu2400

Khshanovych, K. O. How to teach them: the experience of South Korea. Available at: https://vseosvita.ua/news/ ak-navcaut-u-nih-dosvid-pivdennoi-korei-2329.html

Yurchenko, O. 5 stories about the 5 best educational systems in the world. Available at: https://osvitoria.media/ experience/5-istorij-pro-5-najkrashhyh-osvitnih-system-svitu/

Otroshchenko, L. S. (2018). Experience in the management of higher education in Germany. Bulletin of Kyiv National University of Culture and Arts. Series: Management of socio-cultural activities, vol. 32(2), pp. 120-133.

Malik, Ye. A. (2014). Financing of higher education: current trends and foreign experience. Effective economics, vol. 8. Available at: http://www.economy.nauka.com.ua/?op=1\&z=3259

Tuimebaiev, Zh. K. Financing of education in Kazakhstan. Kazakhstan Today news agency. URL: www.kt.kz

Yashchuk, T. A. (2019). The mechanism of financing higher education institutions in the instability of the market of educational services. The dissertation of the candidate of economic sciences: 08.00.03. Pavlo Tychyna Uman State Pedagogical University, 315 p.

Urusova, Z. P. (2013). The role of the state in financing education in Ukraine. Economy and innovative development of the national economy, vol. 6(44), pp. 49-52.

Zhuravel, H., \& Shynkaryk, M. Some aspects of increasing the competitiveness of higher education. Available at: http://visnykj.tneu.edu.ua/index.php/visnykj/article/view/1082

Kozarezenko, L. V. (2010). Socio-economic efficiency of the functioning of educational services. Abstract of the dissertation of the candidate of economic sciences: 08.00.03. Kyiv National Economic University named after Vadym Hetman. Kyiv, $21 \mathrm{p}$.

Malitskyi, B. A., et al. (2004). Rational financing of science as a prerequisite for the development of knowledge society in Ukraine. National Academy of Sciences of Ukraine H.M. Dobrov Center for Scientific and Technological Potential and Science History Studies. Kyiv: Phoenix, 32 p.

Kononenko, O. B. (2017). Current state and trends in state educational policy in Ukraine. National University of Civil Protection of Ukraine (Series: Public Administration), vol. 32(2), pp. 276-287.

Kaleniuk, I. S. (2017). Directions of transformation of mechanisms of financing of education in the modern world. Demography and social economy, vol. 1/29, pp. 24-36.

European penitentiary rules. Available at: https://zakon.rada.gov.ua/laws/show/994_032

Chechyn, M. Yu. (2016). The current state of education of convicts. Scientific Bulletin of the International Humanitarian University. Series: Jurisprudence, vol. 23, pp. 173-176.

Yunkari, T. (2004). Actual problems of the prison service Finland. Proceedings of the international scientific-practical conference. Part 1: Edited by O.H. Kovalev. Moscow: SRI PS (NII UIS) Ministry of Justice of Russia, $111 \mathrm{p}$.

Shevchenko, O. D. (2015). Experience of foreign countries in ensuring the right to education of convicts. Scientific Bulletin of Kherson State University. Series: Legal Sciences, vol. 32(6), T. 3, pp. 76-78.

Pshenychka, Ya. V. (2019). Ensuring the realization of the right to education of convicts in Ukraine and abroad. Molodyi Vchenyi, vol. 3(67), pp. 397-401.

Aleksandrov, Yu. A. Serving a criminal sentence in France and Russia: A brief comparative review. Available at: http://www.index.org.ru/turma/ft/po/020527-3.htm

Aleksandrov, Yu. A. (2005). A day in a French prison. Crime and punishment, vol. 1, pp. 87-120.

Hradetsky, A. V. (2015). Education as a means of correction of convicts. State and regions. Series: Law, vol. 1, pp. 51-55. 